\title{
Ordinary Literacies in Extraordinary Times: Creating Meaning Through Texts, Bodies, and Objects
}

\author{
MAIRI MCDERMOTT \\ University of Calgary
}

ANDREA ROSENFIELD

Concordia University

The theme of Social Sciences and Humanities Congress 2017, Canada: The Next 150-On Indigenous Lands!, was a call to reflect on the past, present, and future. When thinking about the 2017 focus, we (in North America as well as across the globe) were immersed in contentious conversations around the many extraordinary and unbelievable aspects of the US presidential election. Colonial time, as Linda Tuhiwai Smith (1999) and Edward Said (1978) signalled, has closed our imaginations to the cyclical and simultaneity of the past-present-future. These possibilities are replaced by narratives of progress, as a linear path towards improvement, where we can simply leave behind the atrocities of the past. Such narratives confront us as we witness increased intensities between those who are privileged and thos who are marginalized by way of embodied difference. Indeed, in the wake of the midterm elections we continue to feel on edge. Celebrities have stepped into politics and politicians are presented on the entertainment stage as they work to awaken and propel us to recognize the systematic atrocities entangled in our everyday social worlds and global grids of inequitable relations (e.g., \#metoo and \#BLM). These movements, in particular ways, urge us to reconsider situated historical-material embodiments of inequity that are intwined in our seemingly ordinary ways of relating.

The title of the 2017 Congress for Social Sciences and Humanities brings together "Canada" and "Indigenous Lands", calling us to notice the inequitable histories of relations that continue to shape individuals', cultures', and nations' identities. These histories include the socio-matieral and embodied affects which can divide and unite us along multiple and complex alignments. The call encouraged us to reflect on the anniversary of Canada becoming a nation while thinking ahead to the next 150 years. We asked ourselves, what could we possibly imagine for future relations on these lands and what is the role or place of literacy teaching and research in that future? As co-chairs to the Language and Literacy Researchers of Canada (LLRC) pre-conference that year, we were drawn into these everyday extraordinaries, and we asked our contributors to think about the ways in which peope are sense-making with, through, and against embodied encounters with material objects and ever-expanding communicative platforms and textual possibilities.

By positioning ourselves as literacy researchers and educators within this context, we believe we are called to remember that literacy is political; literacy plays a crucial role in today's globally linked classrooms and communities. What role do our literacy practices, approaches, and pedagogies play in shaping how students come to know themselves as literate? How are educators and policy makers supported in recognizing the myriad of literacy possibilities embodied by students, particularly those that are beyond the conventional measurable benchmarks (e.g., Kuby, Spector, \& Thiel, 2018). 
While we recognize that we are living in extraordinary times-technologically, politically, and socially-we are also interested in capturing what our quotidian literacy engagements $d o$. We are curious about the ordinary things we do as part of daily literacy practices - those that are written into curriculum, those that are measured against literacy benchmarks, as well as those that often go unnoticed - the habits and assumptions around what literacy is. We are also interested, importantly, in how our mundane literacy habits affect (e.g., having the capacity to change or move) us. These times require alternative ways of thinking about education, communication, and life.

To ground the conversation, we invited the contributors herein to engage the embodiment and material turns in social science research (see, for example, Enriquez, Johnson, Kontovourki, \& Mallozzi, 2016; Coole \& Frost, 2010) as a possible future for literacy and language research and practice. In this work, the body (as a material discursive entity) is central to the experiences and productions of language and literacy. We hoped this focus might invite us to explore how we assemble communicative and semiotic resources and creativity to make meaning as the human body interacts with material, social, and spiritual spaces through the ordinary textures of everyday life. Sara Ahmed's (2006) work, thus, became a provocateur for the pre-conference:

Objects and bodies 'work together' as spaces for action ... My neck gets sore, and I stretch to ease the discomfort. I pull my shoulders back every now and then as the posture I assume (a bad posture I am sure) is a huddle: I huddle over the table as I repeat the action (the banging of keys with the tips of my fingers); the action shapes me and leaves its impression, through bodily sensations ... I write, and in performing this work I might yet become my object-become a writer, with a writer's body, and a writer's tendencies. (p. 57, emphasis added)

In her above passage, Ahmed (2006) animates for us the ways in which our bodies, as well as our desired identities, are physically and figuratively shaped in dynamic intra-action with particular materials. Her desire to become a writer is contoured through her relation with the desk she is sitting at to perform the writing; the desk makes possible the very act of writing and becoming a writer. The very ordinary act of sitting at a desk to "write" constitutes who she can become. The ways in which her body responds to the repetitive actions of reaching for the keys to type in a seated position change her. The quote, again as a provocateur, braids together the themes taken up in this special issue: the body, the material, and the ordinary in extraordinary literacy times.

Recalling that language is a body technique (Bourdieu, 1991), our attention to the body in literacy engagements is simultaneously an acknowledgement and expansion or rethinking of the discursive emphases in literacy teaching and learning.

In the first article, "Fleeting Encounters and Brick Walls: Animating Embodied Literacies in Our Everyday Relations," Rachael Bell, Katelyn Copage, Matt Rogers, and Pam Whitty (the keynote provocateurs for the pre-conference, this issue) invite us into their ongoing conversations propelled by the conference call for papers. Through the braiding of their individual and co-articulated voices, each author takes us through how the everyday, seemingly ordinary and un-noteworthy literacy experiences accumulate and become embodied through time. In their narratives, sometimes an individual event punctuates a memory culled through sentiments delimiting what a body can do; they invite 
the reader to witness fleeting encounters in their own lives and to rethink our responsibilities to be present in the moment, to disrupt and question the easy answers, and, indeed, the easy questions. Theirs is an ethical call to dwell, as a pedagogy of pause, to turn our attention to the easy slippages into the way things are.

In a differently oriented call to action, Roessingh and Bence (this issue) turn our attention to the sometimes difficult discussions around necessarily repetitive practices in a time when pedagogies of repetition and rote skills have been dismissed as limiting. Their article, "Embodied Cognition: Laying the Foundation for Early Language and Literacy," reminds the reader of the often-overlooked importance of holding a pen(cil) for fluid articulation of ideas. They animate the interconnections between the brain and body (specifically the hands) in shaping the contours of literacy learning in the early years. Through a thorough analysis of the linkages, Roessingh and Bence offer situated practices for educators to support early writers in deveoloping a variety of manual dexterities through play-based pedagogies in support of cultivating writerly dispositions.

While Roessingh and Bence (this issue) invite us to think about the implications of recent technological shifts, with the increase of "writing" on keyboards and tablets, McGlynn-Stewart et al. (this issue), consider how we might engage tablets as intentional sites of literacy learning. In their article, "Open-Ended Apps in Kingergarten: Identity Exploration Through Digital Role-Play," the authors amplify the generative possibilities new technologies can offer in cultivating imaginative identity positions for kindergarteners to embody in the moment. What the article offers is an "and... and" orientation to the triedand-true literacy practices in early years classrooms (e.g., role-playing) and the offerings of new technologies (e.g., tablets). Importantly, this article makes concerted effort to avoid pitting new technologies against historically positioned "best practices". Indeed, one takeaway is the creative ways in which the kindergarten children embodied the tablets as necessary aspects of their role-playing.

Shelley Jones (this issue), in the fourth article, "Educators' Explorations With Gender Performatives and Orientations: A Participatory Action Research Project in West Nile Sub-Region, Uganda," brings the focus back to questions of repetition, this time in the problematics of normative gender performances within patriarchal systems. Jones takes the reader through a week-long educator professional learning series that was focused on gender equality in Uganda. Through a critical consideration of the ways in which gender shapes our grids of relations to humans and non-human others, she amplifies the difficulties and possibiltiies enacted in drawing out how gender performatives shape textual engagements. The educators who participated in the professional learning are physically and figuratively affected by the uncovering of previously unquestioned gender performatives, and the everyday ways in which they embodied limiting gender possibilities for themselves and their students.

Finally, Kevin McBean and Ingrid Johnston (this issue) share their experiences, questions, and embodied discomforts in selecting alternative texts, ones situated outside the conventional English literature canon, for a Grade 10 English Langauge Arts (ELA) classroom in Alberta. In some ways, we might note how extraordinarily ordinary wholeclass text selection is in the ELA classroom, and yet through their explication, we are invited to reconsider the political importance, as well as the potential vulnerabilities, in choosing texts that push us (teachers and students alike) outside of "our" "known 
worlds" - the ways in which our bodies are affected when we are invited into texts that challenge who we think we are.

We hope that through the articles in this special issue, readers will allow themselves to think about their ordinary literacy engagements as embodied entanglements with circulating socio-material-historical discourses, texts, and objects on every level. While each of the articles takes up the focus in variant ways, together they allow us to note the complexities and importance of focusing on the body in literacy education and research.

\section{References}

Ahmed, S. (2006). Queer phenomenology: Orientations, objects, others. Durham, NC: Duke University Press.

Bourdieu, P. (1991). Language and symbolic power. Cambridge, MA: Harvard University Press.

Coole, D., \& Frost, S. (2010). New materialisms: Ontology, agency, and politics. Durham, NC: Duke University Press.

Enriquez, G., Johnson, E., Kontovourki, S. \& Mallozzi, C. A., (Eds.). (2016). Literacies, learning, and the body: Putting theory and research into pedagogical practice. New York, NY: Routledge.

Kuby, C. R., Spector, K., \& Thiel, J. J. (2018). Posthumanism and literacy education: Knowing/becoming/doing literacies. New York, NY: Routledge.

Said, E. (1978). Orientalism. New York, NY: Vintage Books.

Smith, L. T. (1999). Decolonizing methodologies: Research and Indigenous peoples. New York, NY: Zed Books Ltd. 